\title{
Akustinio kraštovaizdžio samprata ir jo tyrimų ypatumai
}

\author{
Ričardas Skorupskas, \\ Saulius Jaruševičius \\ Vilniaus universitetas, \\ M. K. Čiurlionio g. 21, \\ 03101 Vilnius \\ El.paštas: ricardas.skorupskas@gf.vu.lt; \\ saulius.jarusevicius@gf.stud.vu.lt
}

Skorupskas R., Jaruševičius S. Akustinio kraštovaizdžio samprata ir jo tyrimų ypatumai. Geologija. Geografija. 2018. T. 4(1). ISSN 23517549 .

Straipsnyje nagrinėjama kraštovaizdžio garsinės aplinkos struktūra ir identifikuojamos akustinio kraštovaizdžio tyrimų kryptys. Pirmiausia nagrinejjami termino sampratos ypatumai, ypatingas demesys skiriamas akustini kraštovaizdį formuojantiems veiksniams, analizuojama jo erdvinè struktūra, savybès ir garso raiška laiko aspektu. Taip pat identifikuojama ir analizuojama kraštovaizdžio garsų raiškos struktūra skirtingose geografinèse platumose bei vertikalaus zoniškumo srityse.

Be to, straipsnyje akcentuojami probleminiai klausimai, susiję su vienodas akustines savybes turinčių teritorinių vienetų - sonotopų - išskyrimu, pristatomos galimos kraštovaizdžio akustinės aplinkos tyrimų kryptys.

Raktažodžiai: akustinis kraštovaizdis, akustinio kraštovaizdžio struktūra, sonotopai, garsinè aplinka, taikomieji kraštovaizdžio tyrimai

\section{IVADAS}

Garso pojūtis, greta visų kitų žmogaus juslių, yra neatsiejama aplinkos suvokimo priemonè, veikianti bet kuriuo metu ir bet kurioje aplinkoje. Pasak rašytojo Pascalio Quignardo, kontaktas su garsais yra neišvengiamas ir absoliuti tyla negalima (Gedutis, 2016). Akustiniai ir vaizdiniai signalai yra susiję su procesu, kuris padeda individams adaptuotis fizinejje erdveje, suvokti ir suprasti jos vizualinę struktūrą ir garsinę aplinką (Papadimitriou ir kt., 2009). Garsas yra svarbus daugumos sausumos ir vandens ekosistemų komponentas (Farina, 2014). Garsas puikiai perduodamas oru, vandeniu. Be to, dirvožemis ir uolienos taip pat yra pralaidūs garso vibracijai. Garsą kaip reiškinị skirtingais aspektais tiria iqvairios mokslo sritys. Fizikoje gilinamasi i garso prigimtí, savybes, garso bangų sklidimą ịvairiose terpèse ir jų poveiki aplinkai bei atskiriems jos komponentams. Biomedicinos moksluose garsas yra kaip gydymo priemone ir kaip patologiją sukeliantis veiksnys. Jis taip pat aktualus muzikologijoje, architektūroje ir psichologijoje analizuojant jo poveikị žmogaus savijautai. Taigi svarbu konstatuoti, kad garso tyrimai aktualūs tiek fizinių, socialinių, technologinių, tiek ir biomedicinos ar menų mokslų srityse.

Geografijoje, o konkrečiai kraštovaizdžio tyrimuose, garsas taip pat labai svarbus, nes jis yra neatsiejama kraštovaizdžio dalis, pasireiškianti jame bet kuriuo laiku. Garsai yra nuolatine ir dinamiška kraštovaizdžio savybè. Garsas, remiantis gaunamos informacijos kiekiu, po regos yra antras jutimas, kuriuo mes suvokiame kraštovaizdị. Kraštovaizdžio struktūra ir jo garsinè aplinka yra stipriai susietos. Sąsajos pastebimos per kraštovaizdžio morfologiją, augalijos struktūrą, 
žmogaus suformuotus objektus ir infrastruktūrą, gyvūnų pasiskirstymą jame, visa tai generuoja ivairius aplinkos garsus bei jų sklidimo sąlygas (Farina, Pieretti, 2012). Kraštovaizdžio vizualinès savybès šiuo metu yra pakankamai gerai ištyrinètos, tačiau su kraštovaizdžio garsiniu fonu dar tik pradedama susipažinti. Viena iš priežasčių, kad kraštovaizdžio akustinès aplinkos tyrimams reikalingos tam tikros priemonès, būtina tiksli garsą fiksuojanti ir analizuojanti technine iranga. Atsiradus techninèms galimybėms, garso tyrimai tampa vis labiau prieinami kraštovaizdžio bei kitų sričiu tyrejjams. A. Gedutis ir kiti mokslininkai pažymi dar ir tai, kad kitaip nei paveikslų, nuotraukų ar kitos vizualios informacijos, garsų išlikę gerokai mažiau, nes jie nebuvo įrašomi. Kai aptariamas vietos potyris, demesys pirmiausia sutelkiamas $\mathfrak{i}$ vizualius aplinkos objektus ir socialines vertybes, o ne i garsą (Gedutis, 2016).

Kraštovaizdžio akustinių savybių tyrëjams aktuali problema yra terminologija. Šios srities terminologija dar tik formuojasi, todèl neretai yra dviprasmiška ir ne visai aiški. Akustinio kraštovaizdžio terminą įvairios garsą nagrinèjančios mokslo kryptys (pvz., akustika, muzikologija, ekologija ir kt.) naudoja skirtingai. Šiame straipsnyje pagal analogiją su angliškuoju žodžiu soundscape bus vartojama akustinio kraštovaizdžio sąvoka. Tikslus šio žodžio vertimas ị lietuvių kalbą būtų "garsovaizdis“, kurị aiškinant etimologiškai būtų tarsi "garso vaizdas", "garso reginys", o tai ne visiškai tikslu ir akivaizdžiai konkuruotų su „vaizdo reginiu“ ar per regą suvokiama kraštovaizdžio visuma. Dèl to tiriant garsą kraštovaizdyje tiksliau būtų vartoti akustinio kraštovaizdžio sąvoką.

\section{TERMINO SAMPRATOS YPATUMAI IR PIRMŲJŲ KRAŠTOVAIZDŽIO AKUSTINĖS APLINKOS TYRIMŲ APŽVALGA}

Terminas „akustinis kraštovaizdis“ (angl. soundscape) pirmą kartą buvo pavartotas XX a. septintajame dešimtmetyje Kanados kompozitoriaus ir garso tyrejo R. Murray Schaferio ir miestu planavimo specialisto Michaelio Southwortho (Winkler ir kt., 1999). Tačiau tuo metu mokslineje literatūroje neįsitvirtino. Iš pradžių šios mokslų krypties tyrimų laukas nebuvo aiškiai apibrèžtas. Kiek vèliau, XX a. aštuntajame dešimtmetyje,
Kanados kompozitorius B. Truaxas pradejo vartoti "akustinio kraštovaizdžio ekologijos" (angl. soundscape ecology) terminą. Termino „akustinis kraštovaizdis" turinys ir samprata ịvairiose mokslo kryptyse vystèsi skirtingai, todèl šiuo metu egzistuoja nemaža termino apibrèžčų ìvairovè. Vis dèlto dažniausiai vartojamu terminu išlieka soundscape. Akustinio kraštovaizdžio terminas vartojamas daugelyje su erdvinių désningumų tyrimais susijusių mokslo krypčių - nuo urbanistikos iki kraštovaizdžio ekologijos. Aptariama sąvoka yra sudaryta pagal kraštovaizdžio analogiją (Gedutis, 2016) ir susideda iš žodžių sound (garsas) ir landscape (kraštovaizdis) (Féron, 2017). Prie žodžio sound pridedama galūnè - scape (lietuviškai - -vaizdis), taigi lietuviškas termino atitikmuo yra garsovaizdis, jis siejamas su vaizdine informacija, kuri skatina vizualizuoti garsus ar garsinę aplinką (Gedutis, 2016).

Aptinkame ir daugiau akustinę aplinką apibrèžiančio termino įvardijimų. Italų garso ekologas A. Farina teigia, kad paprastai terminas akustinis kraštovaizdis gali būti suprantamas kaip akustinè kompozicija, kurią sukelia natūraliai ar atsitiktinai kylančių fizinès ar biologinès kilmès garsų persidengimas (Farina, 2014). Tai yra labiau muzikinis terminas, nusakantis, kad akustinis kraštovaizdis yra muzikinè kompozicija ar akustinè aplinka, kadangi šioje aplinkoje vyraujantis elementas yra garsas. Taip pat ivvairūs aplinkos garsai yra ịrašomi ir iš jų sukuriama specifinè muzika. Amerikiečių kompozitorè Pauline Oliveros akustinị kraštovaizdị apibūdina kaip visas (garso) bangų formas, aiškiai perduotas mūsų ausies ir jų mechanizmų i̇ mūsų klausos žieves (Oliveros, 2005). Kitaip ji apibūdina pats šio termino autorius kompozitorius R. Murray'as Schaferis. Jis akustinị kraštovaizdị charakterizavo kaip garsinę aplinką, daugybinius garso šaltinius, kurie pasiekia žmogaus ausị (Schafer, 1993). Taip pat teigia, kad kiekvienas sklindantis garsas yra labai svarbus kraštovaizdyje, kiekvienas jo komponentas turi specifinių, unikalių garsų, o visa garsų visuma sukuria tam tikrą skambesí, tam tikrą akustinę aplinką, kas yra suprantama kaip akustinis kraštovaizdis. JAV akustinès ekologijos mokslininkas B. Pijanowski ši terminą suvokia kaip rezultatą sutampančių geofoninių, biofoninių ir antropofoninių šaltinių (kitame skyriuje šie terminai bus paaiškinti išsamiau), kurie yra 
glaudžiai susiję su kraštovaizdžio struktūra ir funkcionavimu (Farina, 2014). Britu aplinkos psichologijos mokslininke Sarah R. Payne apibūdindama akustinị kraštovaizdị akcentuoja ryši tarp individo ar visuomenès suvokimo ir sąveikos su garsine aplinka (Farina, 2014). Žinoma, egzistuoja ir dar daugiau šio termino apibrèžimų ir net apie 12 sinonimų akustiniam kraštovaizdžiui ivardyti, pavyzdžiui, akustinè ar garsinè aplinka, akustinè erdvè ir pan. (Farina, 2014).

Daugumoje Europos šalių šis terminas dažniausiai nusakomas vienodai, tai yra angliško žodžio soundscape vertinys. Švedijoje, Norvegijoje ir Nyderlanduose šis terminas vartojamas kaip analogiškas angliškajam. Pavyzdžiui, Norvegijoje lyd (garsas) + landskap, Nyderlanduose geluids (garsas) + landschap (Dubois ir kt., 2016). Kitose šalyse labai panašiai. Vokiečiai vadina klanglandschaft (garso, garsų kraštovaizdis), italai - paesaggio sonoro (garsinis kraštovaizdis). Prancūzijoje prigijo vertinys paysage sonore (garsinis kraštovaizdis, garsų kraštovaizdis), tačiau akademinè bendruomené dažnai vartoja terminą environnement sonore (garsinè aplinka) arba ambiance (maloni aplinka, atmosfera) (Geisler, 2013). Rusijoje daugiausia vartojamas vertimas звуковой пейзаж (garsinis kraštovaizdis), kai kur gali būti pasitelkiamas ir angliškasis terminas soundscape. Lenkijoje irgi vartojamas analogiškos darybos terminas kaip ir Rusijoje - garsinis kraštovaizdis (lenk. krajobraz dźwiękowy).

Akustinio kraštovaizdžio tyrimų pradžią galime sieti su didesne technine (garso ir vaizdo fiksavimo prietaisai) ir mokslo pažanga, taip pat dèl mokslo pažangos pradètais taikyti tyrimų būdais ir metodais. Pravartu būtų aptarti keletą pirmųjų akustinio kraštovaizdžio tyrimų etapų, kai buvo bandyta garsą kartografuoti. Mokslinèje literatūroje akustinio pobūdžio tyrimų pradžia laikoma XX a. septintasis dešimtmetis, kai pirmą kartą buvo pavartotas šis terminas, tačiau tyrimų būta ir anksčiau. Pradžia siejama su kartografijos priemonių ir metodų panaudojimu tiriant garsus kraštovaizdyje. XX a. trečiajame dešimtmetyje Suomijos geografas J. Gabrielis Granö atliko kiekybinę garso reiškinių klasifikaciją ir pabande pateikti tai kartografiškai. Tyrimui pasirinkta Valoosari vietové, surinkti duomenys buvo sistemiškai suklasifikuoti, bandyta apibūdinti ir suskirstyti garsus pagal pasireiškimo laiką ir daž- nị, taip pat atsižvelgta ị jų natūralumo pobūdị (natūralūs, dirbtiniai garsai) (Radicchi, 2013). $\mathrm{XX}$ a. ketvirtajame dešimtmetyje amerikiečiu ekologas A. Leopoldas analizavo paukščių garsus ir iškèlè hipotezę, kad paukščiai dainuoja reaguodami $\mathfrak{t}$ dienos šviesą. Jis neturejjo garso įrašymo irangos, tačiau kruopščiai savo užrašuose atsižvelgdamas ị laiką ir insoliacijos ryškumą (ịvertinta šviesos matuokliu) žymèjo, kada kiekvienos rūšies paukščiai pradeda savo rytines giesmes (Andrews, 2013).

M. Southworthas 1967 m. kraštovaizdžio garsinès aplinkos tyrimus vykde urbanizuotoje aplinkoje. Miestų planavimo disertacijoje jis išdèstè tezes ir panaudojo pavadinimą "garsinè miestu aplinka“. Mokslininkas analizavo garsini kraštovaizdi teritorijoje, esančioje tarp Beacon Hillo ir Wharfo kvartalų Bostono miesto centrinejje dalyje. Jis atkreipé dèmesị $\mathfrak{z}$ du aspektus. Pirma, nustate garsu „tapatybę“ ir „informatyvumą“, tyrinèdamas jų sąveiką analizuojamoje vietoveje. Antra, išanalizavo skleidžiamų garsų „žavesį“, t. y. savybes, kurios, jo nuomone, yra labiau ar mažiau priimtinos. Be to, M. Southworthas atskleide ryši tarp vizualinio ir girdimojo suvokimo, kad būtu suprantama, kaip fiziniai duomenys ir erdviniai bruožai veikia tam tikro akustinio kraštovaizdžio elemento tapatumą (Radicchi, 2013).

1975 m. mokslininkas R. Murray Schaferis, vykdydamas pasaulio akustinio kraštovaizdžio tyrimus (World Soundscape Project) ir kartografuodamas, panaudojo terminą "garsų žemèlapis“ (Radicchi, 2013). Šis projektas buvo pavadintas „5 miestų garsinis kraštovaizdis“, jam atlikti pasirinkti penki Europos miestai ir vykdytas ju palyginimas. Tyrimo tikslas buvo ekstrapoliuoti reikiamą informaciją tiriant kiekvieno miesto akustinị foną. Šiame tyrime siekiant pavaizduoti miesto garsinę aplinką buvo naudojami detalesni tyrimai, pavyzdžiui, panaudoti brèžiniai ir kt. Taip pat šis mokslininkas išplètojo garsinès aplinkos tyrimų koncepciją ir įvairias teorijas. Tai turejjo ittakos kitų šios krypties mokslininkų darbams.

Tolimesni tyrimai daugiausia buvo skirti įvairių urbanizuotų teritorijų analizei, tačiau tobulèjant technologijoms pradèti ir vandens ekosistemų, gyvosios gamtos skleidžiamų garsų tyrimai, jie vykdyti ir vykdomi įvairiose pasaulio vietose. Visi tyrimai yra tarpusavyje susiję, kiekvienas iš jų 
nagrinejja aplinkos akustinị kraštovaizdị ịvairiais aspektais. Pagrindiniai tyrimų klausimai, kurie ne mažiau aktualūs ir kraštovaizdžio geografijai, ir kraštotvarkai, yra: (1) koks ryšys tarp žmogaus ir garsų, sklindančių jo aplinkoje; (2) kas nutinka, kai šie garsai pasikeičia (Schafer, 1993).

\section{GARSO ŠALTINIAI IR JŲ RAIŠKA KRAŠTOVAIZDYJE}

Pasaulio akustinè kraštovaizdžio struktūra nuolatos kinta ir evoliucionuoja, sparčiausi ir radikaliausi pokyčiai vyksta dèl vis intensyvèjančios ìvairaus pobūdžio žmonių veiklos. Ši kaita kraštovaizdyje pasireiškia kaip naujų garsų atsiradimas, kurie labai skiriasi kokybe ir intensyvumu nuo praeityje vyravusių garsų, ypač padaugèjo ịvairių garso šaltinių (Schafer, 1993). Garsus skleidžiančių prietaisų, procesų ịvairové šiuo metu ypač plati. Klausa suvokiamų garsų visuma leidžia identifikuoti ìvairias vietoves. Garso raiška ir sklidimas priklauso nuo: geografinès padèties, jo garsumo, aukštumo, registro, tembro, trukmès, pasikeitimo dažnio, sklidimo sekos, laiko, per kiek jis pasiekia minimalią ir maksimalią reikšmes (Holmes, 2016). Visą tai galima įvardyti kaip garso savybes. Ivairūs garsai ilgainiui kinta, tai ypač pastebima vidutinių platumų sąlygomis, kur ryškiai išsiskiria keturi metų laikai.

Iki šiol (gana ilgą laiką) akustinio kraštovaizdžio tyrimuose vyravo îprasta garsų šaltinių klasifikacija. Išskiriami trys garso kraštovaizdyje dominuojančių garsų šaltiniai: geofonija, biofonija ir antropofonija. Tačiau toks skirstymas nèra tikslus ir išbaigtas. Todèl šio straipsnio autoriai siūlo papildytą ir tikslesnę klasifikaciją. 1 pav. autorių apibendrinta ir išreikšta schematiškai bendroji akustinio kraštovaizdžio struktūra, ivvardijami garso šaltiniai kraštovaizdyje ir ryšiai tarp jų.

Pirmasis - bazinis garsu šaltinis, pasireiškiantis kraštovaizdyje, yra geofonija (1 pav.), kuri tiesiogiai

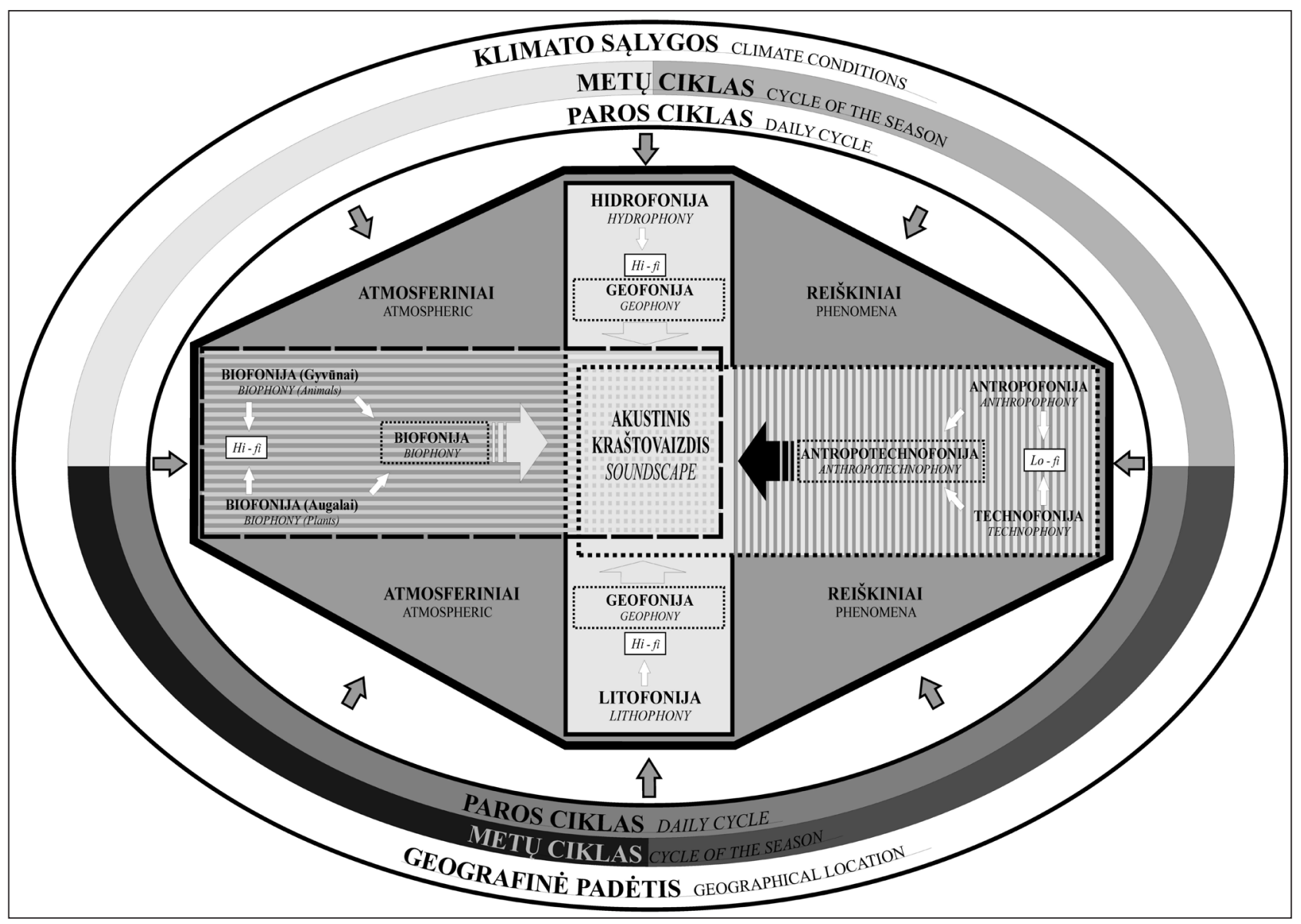

1 pav. Akustinio kraštovaizdžio struktūra

Fig. 1. Soundscape structure 
susieta su kraštovaizdžio fiziokompleksu. Geofonija yra ne biologinès kilmès, t. y. litomorfinio pagrindo, vandens ir meteorologinių reiškinių sukeltu garsu rezultatas. Prie geofonijų priskiriami tokie reiškiniai kaip vèjas, ugnikalnių išsiveržimai, jūros bangavimas, tekantis vanduo, lietus, perkūnija, lavinos, žemès drebejjimai ir potvyniai, be to, šių reiškinių garsai parodo pirminị garsinị foną, kuriame jie gali maišytis, persidengti su kitais garsais ar užsimaskuoti (Farina, 2014).

Geofoniniai garsai stipriai priklauso nuo teritorijos geomorfologinių bruožų (pvz., šlaitų statumo ar padèties), vietovès klimato sąlygų, konkrečios vietos orų režimo, jų sąlyčio su savitu paviršiumi. Geofoniniai garsai reiškiasi tiek žemosiose platumose (natūralūs hidrologiniai, geofiziniai ir geocheminiai procesai kalnuose), tiek ir aukštosiose (snigimas, sniego judejimas). Geofonija formuojama iš trijų pagrindinių komponentų: žemès paviršiaus, vandens ir vejjo veiklos. Todèl tiksliau būtų juos atskirti ir teigti, kad geofoniją sudaro hidrofonija (tekančio ar banguojančio vandens sukeliami garsai) bei litofonija (garsai, atsirandantys judant litomasei arba vejo sąlytyje su žemés paviršiumi). Šiuo atveju geofonija įvardijama kaip vejjo ir kitų meteorologinių reiškinių veikla - pagrindinis veiksnys, lemiantis hidrofonijos ir litofonijos raišką. Vejjas ir kiti rečiau pasireiškiantys meteorologiniai reiškiniai sukuria ịvairias garsų variacijas. Vejjo sukuriami garsai priklauso nuo geografinès aplinkos ypatybių, taip pat ir paklotinio paviršiaus (kalnai, lygumos, slèniai, miškas, pieva, dirbamas laukas ir kt.). Vejją kaip meteorologinị reiškinit galima sieti su del įvairiais atmosferos ir paklotinio paviršiaus kontakto vykstančiais procesais, kurie turi reikšmingos ịtakos garsų raiškai. Taigi geografinès sąlygos ir klimatas kraštovaizdžio garsams suteikia tam tikrus, tik tai vietovei būdingus, pagrindinius garsus. Vietovès morfologija, slènių, kanjonų, uolų būvimas teritorijoje nulemia skirtingą garsų sklidimą, taip pat šie kraštovaizdžio komponentai turi itakos garso bangų slopimui. Brizas, oro drègnis ir temperatūra veikia garso bangu sklidimo ypatybes (Farina, 2014). Vandens terpejje garsų sklidimui įtakos turi gylis, druskingumas ir temperatūra. Geofoniniai garsai kinta sezoniškai ir per parą (Pijanowski ir kt., 2011). Tokio meteorologinio reiškinio kaip lietus sukuriami garsai taip pat labai skiriasi, jų pobūdis ir kaita akivaizdžiai priklauso nuo lietaus pobūdžio ir intensyvumo. Garsai priklauso ir nuo to, ant kokio paviršiaus (objekto) krinta lašai, ar tai namo stogas, akmuo, medžių lapai, vandens telkinys ir t. t., kadangi kiekviena aplinka ir medžiaga pasižymi skirtingomis akustinèmis savybėmis. Vandens garsinė aplinka skiriasi ir priklausomai nuo metų laiko, pavyzdžiui, žiemą vyrauja ledas ir sniegas. Ledo ir sniego skambesys priklauso nuo temperatūros, sniegas sugeria garsus, todèl sningant issivyrauja tyla.

Antrasis garsų šaltinis - biofonija. Tai yra gyvų organizmų skleidžiami garsai, susiję su biomais, stambiomis ar lokaliomis ekosistemomis. Kiekvieno biomo viduje atskiras kraštovaizdžio plotelis (ekotopas) turi skirtingus biofoninius garsus. Italijos akustinès ekologijos specialistas A. Farina prie šių garsų priskiria ir žmonių balsus. Tokio pobūdžio garsai turi skirtingą struktūrą, priklausomai nuo geografinès platumos, metų ar paros laiko. Pastebima ir gyvūnų skleidžiamų garsų kaita, pasireiškianti skirtingu metų ar paros laiku ir išryškejjanti tam tikromis valandomis (pvz., paukščiai ir varlès „dainuoja“ chorais aušros ir sutemų metu), taip pat sezoniškai (pvz., paukščiai yra akustiškai aktyvesni pavasarị) ir priklausanti nuo geografinèse padeties (pvz., subekvatorineje klimato zonoje paukščiai čiulba visus metus, o aukštesnèse platumose jie tylūs, išskyrus perèjimo sezoną) (Farina, 2014). Gyvūnų garsai (ypač vabzdžių) kinta ịvairiu metų laiku, priklausimai nuo fenologiniu reiškinių ir klimato pokyčių (Pijanowski ir kt., 2011). Kiekvienas gyvūnas skleidžia savitus garsus. Dažniausiai girdimi yra paukščių ir vabzdžiu garsai (Schafer, 1993). Tai gali būti perspejjamieji garsai, išgąsčio, poravimosi, maisto apsikeitimo tarp motinos ir jauniklių, valgio ar bendravimo. Visi garsai skiriasi intensyvumu, jiems būdinga didelè ịvairovè (nuo čiulbejjimo ar švilpavimo iki kriuksèjimo ar riaumojimo). Pastebèta, kad organizmo fiziniai bruožai, tokie kaip jo kūno dydis, trachejos ilgis ir snapo struktūra, lemia, koki garsą tam tikras organizmas išgaus (Pijanowski ir kt., 2011). Pavyzdžiui, kuo organizmas didesnis ir su didesne trachejja, tai jis paprastai išgauna žemesnio dažnio garsus nei mažas paukštis su mažesne trachejja. Stipriausius garsus išgauna sausumos stuburiniai ir tam tikros vabzdžiu grupès. Pavyzdžiui, vabzdžiai stipriausius garsus skleidžia nuo 
3 iki $4 \mathrm{kHz}$ ir nuo 6 iki $8 \mathrm{kHz}$. Tokiu garsų dažniu pasižymi intensyviausią garsą skleidžiantys vabzdžiai, pavyzdžiui, svirpliai, žiogai, cikados (Pijanowski ir kt., 2011). Be to, daugumos vabzdžių giesmès periodiškai kinta, jie jas gieda tam tikrais intervalais arba atsižvelgdami i meteorologines sąlygas. Vabzdžiams, paukščiams, sausumos gyvūnams, amfibijoms būdingas cikliškas garsų skleidimas, pavyzdžiui, gieda tik tam tikru paros (diena, naktis) ar metų laiku (Pijanowski ir kt., 2011). Sausumos gyvūnai labai svarbūs, jie sukuria garsų i̇vairovę. Tai primatų (beždžionès ir kt.), dramblių, graužikų (voverès ir kt.), kačių (liūtai) grupių skleidžiami garsai. Anksčiau pateiktoje akustinio kraštovaizdžio struktūroje tai apibūdinama kaip gyvūnijos sukeliami garsai ir demesys kreipiamas tik $\mathfrak{i}$ juos. Augalų sukeliami garsai tarsi neegzistuoja, nes jie daugelyje skirstymų nèra ịtraukti ị garso šaltinių struktūrą, nèra traktuojami kaip garso šaltiniai. Žinoma, patys savaime augalai skleidžia žmogaus ausiai negirdimo dažnio garsus, todèl jų, atsižvelgiant Ł̇ žmogaus klausos diapazoną, negalime traktuoti kaip suvokiamus garsus. Augalų skleidžiamus garsus teisingiausia būtų ịvardyti kaip vẻjo, lietaus dèl kontakto su augalais atsirandančius garsus (judinamų lapų ir lajos keliami garsai).

Trečioji garso šaltinių grupè yra antropofoniniai garsai. Antropofonija yra visų judančių ir žmogaus sukurtų prietaisų skleidžiamų garsų rezultatas, pavyzdžiui, automobilių, traukinių, lèktuvų, industrinių prietaisų ar varpų (Farina, 2014). Tai yra diskutuotinas apibrěžimas, ne visi mokslininkai su tuo sutinka. Vieni iš jų šiai grupei priskiria tik prietaisų skleidžiamus garsus. Kiti priskiria tik paties žmogaus sukeliamus garsus (kalbẻjimas, dainavimas ar panašaus pobūdžio garsai), ỉ šią grupę neįtraukia žmogaus sukurtų ir garsus skleidžiančių prietaisų. Pasak filosofo A. Gedučio, šis terminas nèra pakankamai aiškiai apibrèžtas, todèl vertètų išskirti žmogaus natūraliai skleidžiamus garsus ir žmogaus sukurtų ar sukonstruotų objektų skleidžiamus garsus. Taigi tiksliau būtų atskirti šiuos du garso šaltinius, išskiriant antropofoniją kaip pačių žmonių skleidžiamus garsus bei žmogaus valdomų ar savaime veikiančių prietaisų skleidžiamus garsus - technofoniją. Šią garso šaltinių grupę bendrai galima ivvardyti sudurtinių terminu antropotechnofonija. Antropofoniniai garsai tampa dominuojantys vis didesneje planetos dalyje, nes yra susiję su miestų plètra ir globalizuota prekyba. Antropofoniniu garsų intensyvumas išauga artëjant prie urbanizuotos aplinkos bei netoli pramoninių teritorijų ir transporto koridorių (automagistralių, oro uostų). Antropofonijos pobūdis kinta priklausomai nuo miestų funkcijos, struktūros, socialinio ir ekonominio konteksto (Farina, 2014).

Pastebimos glaudžios sąsaja tarp paminètu trijų stambių garso šaltinių (1 pav.). Stipriausi yra antropofoniniai ir geofoniniai garsai, kurie dažnai prislopina biofonijos garsus. Be to, urbanizuotose teritorijose žmogiškosios kilmės garsai dažnai išskiriami tada, kai triukšmas užgožia geofoniją ar biofoniją. Gerai išreikšti antropofoniniai ir geofoniniai garsai keičia gyvųjų organizmų skleidžiamų garsų pobūdị (perspejjamieji signalai, šauksmas). Būtina pabrěžti, kad geofoniniai garsai pirmiausia turi tiesioginę itaką biofonijai, kiek mažiau antropofonijai, o antropofonija gali paveikti biofoniją (Farina, 2014). Pavyzdžiui, vèjuotą dieną daugumos gyvūnų skleidžiami garsai yra prislopinami vejjo. Stipri antropofonijos garsų itaka biofonijai yra tada, kai jie yra labai aukšti, pavyzdžiui, arti oro uosto, o vandenų gyvūnų garsų sklidimui didelę ịtaką turi laivų variklių ar gręžimo platformų skleidžiami garsai.

Visų anksčiau išvardytų garsų šaltinių raišką ir jos dinamiką iš esmès lemia trys pagrindiniai veiksniai, svarbiausias iš jų - geografinè padètis, kuri turi ittakos metų bei paros ciklo kaitai. Šie veiksniai lemia garsų ịvairovę, pasikartojimo dažnị, intensyvumą ir kita. Paros ciklas būdingas didžiajai daliai garso šaltinių, tačiau aiškiausiai garsų kaita per parą pastebima tarp biofoninių (gyvūnai) ir antropotechnofoninių garso šaltinių. Analogiška arba labai panaši garso dinamika pastebima tarp žmonių ir tarp jo sukurtų bei veikiančių technogeninių objektų. Geriausiai išreikštas ciklas yra diena-naktis, tačiau didieji pasaulio miestai ir ypač technogenizacijos židiniai (stambių įmonių teritorijos) išlieka labai triukšmingi net ir naktị.

Remiantis aplinkos garsus tiriančių mokslininkų supratimu, gali būti išskiriamos dvi garsinio kraštovaizdžio savybes identifikuojančios ypatybès, ịvardijami kaip hi-fi (angl. hight-fidelity) ir lo-fi (angl. low-fidelity) garsai (1 pav.). Tam tikri abstraktūs $h i-f i$ (aukšto tikslumo) garsai gali būti aiškiai girdimi kai nèra jokio papildomo triukšmo, 
net ir kai garsų sklidimas ribojamas, jis išlieka pakankamai aiškus (Schafer, 1993). Kaimiškame kraštovaizdyje tokio pobūdžio garsai pasireiškia gerokai dažniau nei urbanizuotoje aplinkoje. Taip yra todèl, kad gamtinis (natūralus) kraštovaizdis sukuria galimybę išgirsti iš vieno netoli esančio ar kiek nutolusio garso šaltinio sklindanti garsą daug aiškiau. Be to, kaimiškoje aplinkoje yra maži eismo srautai, nèra pramonès, nèra kitokių papildomų stiprių garsų. Pavyzdžiui, vištų ar naminių gyvulių skleidžiami garsai, varpų skambesys, šiaudų traškejjimas ir pan. gali būti aiškiai ir be jokių trikdžių girdimi (Papadimitriou ir kt., 2009). Kaimiškoji aplinka pasižymi tylesniais garsais nei miestiškoji. Tai vadinamoji „tylioji aplinka“, kuri gali būti traktuojama kaip tam tikras akustinio kraštovaizdžio tipas, turintis unikalų bruožą - tylą. Kaimiškosios aplinkos garsai, kai kurių autorių ìvardijami kaip erdvèvaizdis (angl. enviroscape), kuris jungia agrarines ir miškingas teritorijas, krūmynus, pavienius ùkius, miestelius, mažus upelius ir kitus vandens telkinius, labai riboto eismo nedidelius kelius ir šaligatvius (Pijanowski it kt., 2011).

Lo-fi (žemo tikslumo) garsai kraštovaizdyje yra neaiškiai išreikšti ir sunkiai suprantami, nes jie užgožiami kitų, aukštesnio dažnio ir geriau išreikštų garsų, sklindančių iš keleto garso šaltinių vienu metu (Schafer, 1993). Lo-fi garsai akustiniame kraštovaizdyje pasižymi tuo, kad yra šalia vienas kito ir išsidèstę itin kompaktiškai. Tokie garsai būdingi urbanizuotai aplinkai, kadangi čia vyrauja didelè garso šaltinių ir garsų ìvairovè. Jie tarpusavyje persipina, todèl sunku išgirsti vieną dominuojantị ir aišku garsą. Pavyzdžiui, paukščių garsai ir vejjas, nors ir skleidžia stiprius garsus, vis tiek laikomi harmoningi aplinkoje, t. y. dera tarpusavyje. Sausumos ar oro transporto keliami garsai tarpusavyje yra neskambūs - kakofoniški. Jų kuriami garsai yra skirtingo spektro ir dažnio. Transportas, žmonių srautai, ịvairūs darbinių mašinų ir panašaus pobūdžio garsai miesto aplinkoje susilieja. Urbanizuotose teritorijose garso šaltiniai taip pat yra labai ịvairūs, pavyzdžiui, miesto gatvèse judantys automobiliai, viešojo transporto srautai, prekybos centrai ir jų aikštelès, geležinkelio stotis, oro uostas, vaikų žaidimų aikštelès, miesto viešosios erdvès ir pan. Šiuos garsus dažniausia sukelia įvairi žmonių veikla, skleidžia jų sukurti įrenginiai. Pagrindinis žodis, apibūdinantis miesto garsinę aplinką, - triukšmas.
Garsą nusako kokybinès (dažnis) ir kiekybinès (slègio lygis) charakteristikos. Jų erdvinès ir laiko variacijos sukuria dinamišką garsų skambesị kraštovaizdyje. Akustine aplinka tampa svarbiu informacijos šaltiniu, kai aplinkoje pasireiškia dviejų tipų garsai. Pagrindiniai (pirminiai) garsai (angl. foreground) lokaliame lygmenyje yra nenuspejjami laike ir erdveje, t. y. galintys pasireikšti bet kuriuo paros metu, ir cikliški akustinio fono garsai (angl. background), kurie tampa orientyru tam tikriems organizmams (Farina, 2014). Pagrindiniai arba pirminiai garsai gali kilti staiga dèl tam tikrų priežasčių, pavyzdžiui, griaustinio garsas, gyvų organizmų garsai, girdimi norint tam tikrais signalais išreikšti svarbią informaciją. Jie dažniausiai yra geofoninių ir antropofoninių garsų rezultatas (Farina, 2014). Tokio pobūdžio kraštovaizdžio garsai priklauso nuo vietovès geografinès aplinkos, klimato, vandens, vèjo, miškų, lèktuvų, gyvūnijos (vabzdžių, paukščių) ir kt. (Schafer, 1993). Pagrindiniai garsai aplinkoje kinta priklausomai nuo metų laiko, aplinkos meteorologinių sąlygų, pavyzdžiui, lyjant vyrauja vienoki garsai, sningant, esant iprastoms meteorologinems sąlygoms, kitokie ir pan. Šio tipo garsai sklisdami kraštovaizdyje sukuria laikinas garsų konfigūracijas, o foniniai garsai mažiau kinta ir labiau priklauso nuo kraštovaizdžio ypatybių, kadangi juos veikia geofoniniai ir antropofoniniai garsai. Akustinio fono garsai dažnai yra žemesnio dažnio, jie gali kilti iš skirtingu šaltinių, tačiau slopsta sklisdami tolyn, jie yra kaip orientyras, pavyzdžiui, žinduolius baido girdimas automagistralès triukšmas, todèl mažèja susidūrimų su transporto priemonemis (Farina, 2014). Garsų intensyvumui ir trukmei ittakos turi ir tam tikro gamtinio reiškinio trukmè, jo stiprumas. Pavyzdžiui, silpnas ir stiprus lietus sukuria skirtingus garsus tam tikruose kraštovaizdžio komponentuose. Kraštovaizdžio komponentai turi įtakos garso sklidimui aplinkoje: vieni silpnina, kiti stiprina garsą, pavyzdžiui, miško pakraštys ir uola. Išryškejja viena iš esminių akustinio kraštovaizdžio savybių - dinamiškumas.

\section{GARSŲ RAIŠKOS DINAMIKOS GEOGRAFINĖ DIFERENCIACIJA}

Kaip buvo minèta nagrinejjant garsų šaltinius, kraštovaizdžio akustinès struktūros sandara ir jos kaitos pobūdis per metus ir parą ypač priklauso 
nuo vietos geografinès padèties bei klimatinių ypatumų, kurie dèl santykio su kitais kraštovaizdžio fiziosferos, biosferos ir antropotechnosferos komponentais formuoja vienokią ar kitokią akustinę aplinką. Esama akustinès aplinkos ịvairove ir jos ryški priklausomybė nuo vietos sąlygų apsunkina tiriamo požymio ar kai kurių jo charakteristikų atvaizdavimą geografinio pobūdžio schemose. Tačiau laikantis apibendrinančio požiūrio ir remiantis santykinemis kategorijomis, kurios nesusietos su konkrečių parametrų reikšmėmis pagal vietovès geografines sąlygas, imanoma pavaizduoti apibendrintą metų laikams ir kraštovaizdžiui būdingą pasireiškiančių foniju garso raiškos intensyvumą santykinejje skalejje ir skirtingose geografinèse platumose (2 pav.). Suformuotą ir generalizuotą schemą galima taikyti tiek šiauriniam, tiek pietiniam pusrutuliams, orientuojantis í žemumų teritorijas, kurios virš jūros lygio nepakilusios aukščiau kaip $500 \mathrm{~m}$. Reikètų pabrèžti, kad tai yra stipriai generalizuota schema, netaikytina lokaliame lygmenyje, bet labiau padedanti suvokti akustinio kraštovaizdžio platuminès diferenciacijos dèsningumus.

Vietos akustinę kraštovaizdžio struktūrą lemia daug geografinių veiksnių, vienas svarbiausių yra klimato sąlygos, nuo kurių labai priklauso krituliu kiekis ir ju režimas bei sezoninė oro temperatūros dinamika. Antriniai, tačiau ne mažiau svarbūs veiksniai yra vietovès paviršiaus dangos ypatumai, augalijos dangos pobūdis, gyvūnijos ịvairové, gyventojų skaičius, antropogenizacijos lygis ir t. t. Taigi nuo įvairių vietovès geografinių sąlygų ypatumų labai priklauso atitinkamų garso šaltinių raiškos galimybès, pasikartojimo dažnis, intensyvumas, dinamika ir kiti parametrai. Kraštovaizdžio akustinè struktūra, būdama ypač priklausoma nuo geografinių sąlygų, pastebimai kinta tiek platumos, tiek ir vertikalia kryptimi.

Kraštovaizdžio akustinès struktūros pokyčiai vertikalia kryptimi turi glaudų ryši su vertikaliojo zoniškumo sritimis ( 3 pav.). Keičiantis vietos aukščiui virš jūros lygio, kinta kraštovaizdžio struktūra, ji sudarančių komponentų savybès. Ivardyti pokyčiai tapatūs arba labai panašūs kaip ir keičiant padèti platumos kryptimi iš pietų i šiaurę. Pateikiamas generalizuotas akustinio kraštovaizdžio vertikalios diferenciacijos (pagal atskirus garso šaltinius - fonijas) modelis yra tampriai susietas su sąlygu pokyčiais, pasireiškiančiais platumos kryptimi. Reikètų pabrèžti, kad pastaroji schema (modelis) yra apibendrinta ir supaprastinta, todèl

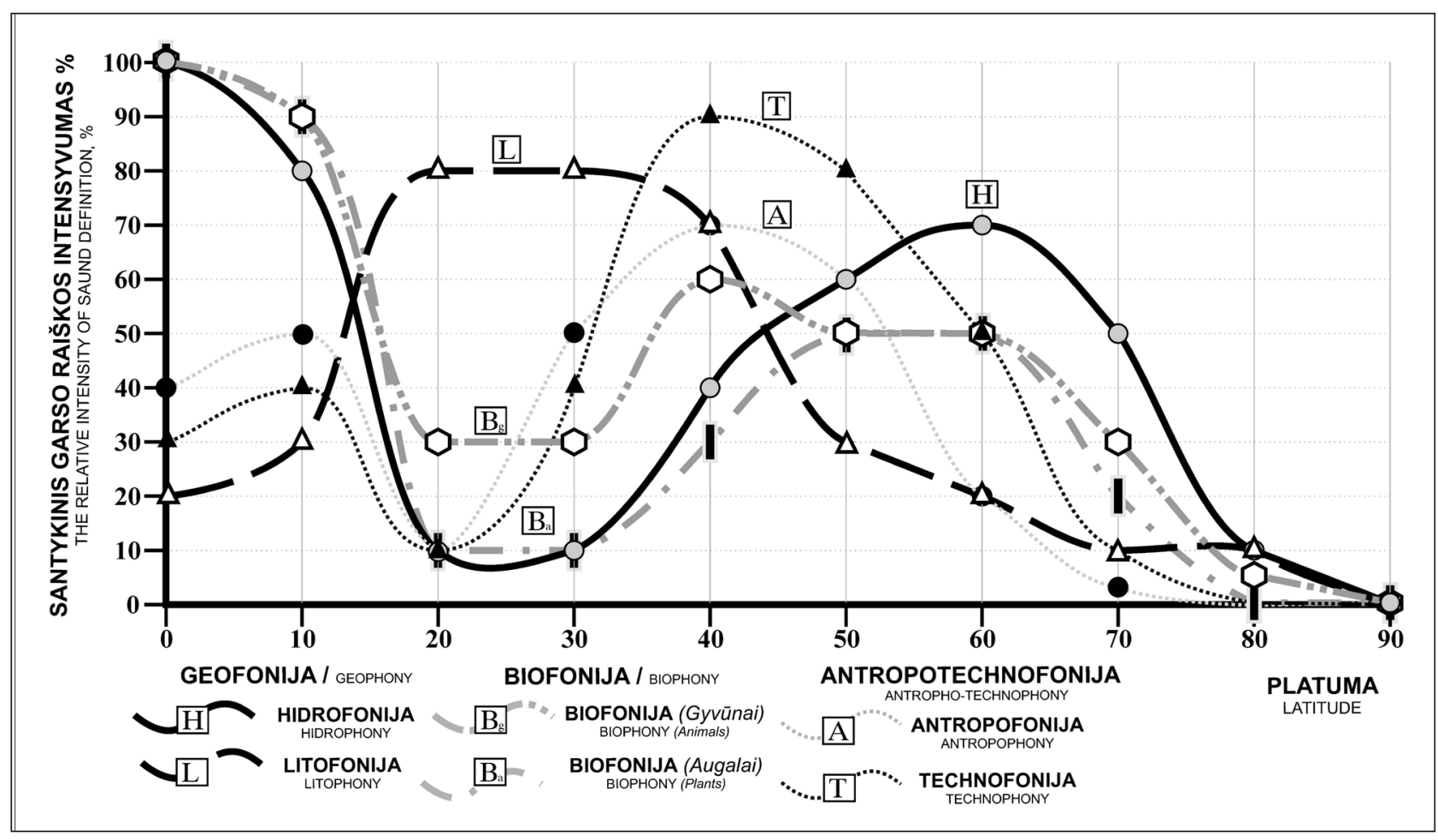

2 pav. Santykinis garso raiškos intensyvumas geografinèse platumose

Fig. 2. The relative intensity of sound definition in the latitudes 


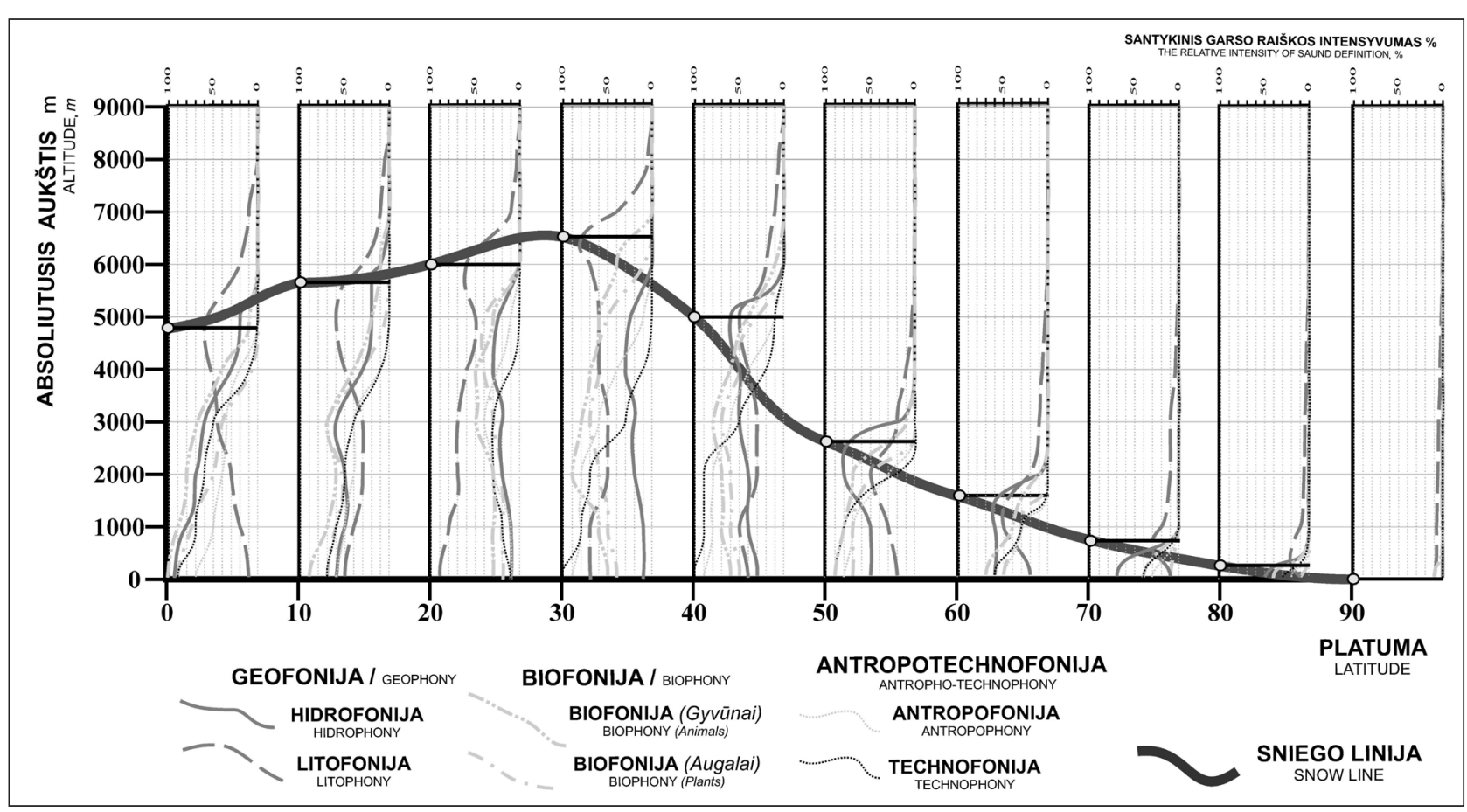

3 pav. Garso raiška vertikaliojo zoniškumo srityse

Fig. 3. The intensity of sound in the areas of altitudinal zonation

konkrečios vietos kraštovaizdžio akustinès sąlygos gali pastebimai skirtis. Galimi neatitikimai dèl geografinès vietovès sąlygų, kurių įvairovè kalbant apie vertikalųji zoniškumą yra nepalyginamai didesnè nei platumos kryptimi. Pastarojoje schemoje (3 pav.) kraštovaizdžio akustines savybes reikšmingai keičia sniego riba, aukščiau kurios didesnè arba net absoliuti dauguma garso šaltinių nusilpsta ar net nustoja reikštis. Sniego linija, žvelgiant nuo pusiaujo ašigalių link, kyla ir ties Himalajų kalnų masyvu pasiekia aukščiausią atžymą - apie 6 000-6 800 m., o einant ị aukštesnes platumas - žemejja, aukštosiose platumose nusileisdama beveik iki jūros lygio. Sniego riba iš esmès veikia kaip kraštovaizdžio akustinių savybių raišką limituojantis veiksnys. Lygiai taip pat kaip sezoninejje kraštovaizdžio akustinių savybių dinamikoje šaltasis (žiemos) laikotarpis, kuris apriboja daugumos garso šaltinių raišką.

\section{AKUSTINIO KRAŠTOVAIZDŽIO TYRIMŲ YPATUMAI}

Akustinė kraštovaizdžio struktūra, būdama reikšminga užtikrinant visavertes žmogaus ir kitų biologinių organizmų funkcionavimo sąlygas, iki šiol išlieka sunkiai kartografuojama. Daugeliu atvejų mokslinio pobūdžio tyrimai yra orientuoti ne $\mathfrak{i}$ kraštovaizdžio akustinių savybių ir jų dinamikos ypatybių išaiškinimą, bet ị akustinès ir garsinès taršos analizę urbanizuotose teritorijose. Vienas svarbiausių kraštovaizdžio akustinès aplinkos tyrimu metodų yra geografinio-sociologinio pobūdžio. Tokio pobūdžio tyrimai dažniausiai vykdomi pasitelkiant vietinius gyventojus, vaikštinejant tam tikroje aplinkoje pildomos anketos (angl. soundwalk). Jas sudaro vertinimo skalès ir žmonių komentarai, formuojami tam tikroje geografinejje garsinejje aplinkoje. Remiamasi klausimynais ir stebejimo dalyviu patirtimi, jžvalgomis bei lūkesčiais (Brooks ir kt., 2014). Kitas analogiško tyrimo būdas yra susijęs su žmonių apklausa naudojant semantinio diferencialo metodą. Atsakant ị klausiamą, kokie pojūčiai kyla būnant tam tikroje (garsinèje) aplinkoje, žmonès savo pojūčius išreiškia ịvairiausiais teigiamos ir neigiamos prasmès būdvardžiais. Per pastaruosius dešimtmečius šis tyrimų metodas labiau sutelktas ties veiksniais, kurie lemia žmonių supratimą apie tam tikras vietoves (Brooks ir kt., 2014).

Vis labiau populiarejja kraštovaizdžio akustinès aplinkos tyrimai ekologiniu aspektu (angl. soundscape ecology). Tai yra nauja mokslo kryptis. 
Daugelis pagrindinių šios krypties principų yra žinomi ir ịprasti kraštovaizdžio ekologijos mokslui. Tai daugiausia susiję su geografiniu konteks$\mathrm{tu}$, antropogeninių ir biologinių procesu identifikavimu, ìvairiais aplinkos garso spektriniais modeliais tam tikru laiko momentu. Akcentuojama antropogeninių ir biologinių garsų sąveika, kaip gyvieji organizmai suvokia kraštovaizdžio erdvinę konfigūraciją ir pan. (Pijanowski ir kt., 2011). Šios krypties tyrimuose svarbiausi šie analizavimo būdai: akustinès kraštovaizdžio aplinkos kiekybinis matavimas, erdvès ir laiko dinamika, aplinkos kaitos poveikis garsui, kraštovaizdžio garsų įtaka gyvajai gamtai, žmogaus poveikis kraštovaizdžio garsams ir kraštovaizdžio garsų poveikis žmogui. Dažniausiai tokio pobūdžio tyrimai vykdomi konkrečioje lokalaus lygio vietoveje. Sparčiai besiplètojanti yra jūros ar vandenyno akustinès aplinkos tyrimu kryptis. Analizuojant povandeninès aplinkos garsus yra sužinoma apie geofizinius reiškinius, orų sąlygas, vietinius gyvūnus ir žmogaus veiklą tam tikroje vietovejje (Erbe ir kt., 2016).

Kraštovaizdžio geografijoje ir kraštotvarkoje garsas gali būti tiriamas struktūriniu ir morfologiniu principu, kaip sudedamoji ir neatsiejama kraštovaizdžio dalis. Garsinès aplinkos tyrimai galimi ịvairiais aspektais, jie apima tiek visuomeninès (urbanizuotos, kaimiškosios teritorijos) tiek gamtinès geografijos (kraštovaizdžio komponentų sukuriami garsai, gyvoji gamta) sritis. Kraštovaizdžio geografiniai, erdviniai bruožai yra išreiškiami kartografiškai. Tiriamoje (kartografuojamoje) teritorijoje pagal garso intensyvumą yra išskiriami arealai, kuriuose garsas išreiškiamas decibelais. Analizuojant kartografuotas vienodo garso stiprumą jungiančias linijas matoma, kiek žmonių yra paveikiama skirtingo intensyvumo garsų. Santykinai daug tyrimų yra atliktų oro uosto zonose identifikuojant lèktuvų skleidžiamo garso stiprumą ir jo poveiki aplinkinèms teritorijoms, jų kaitą tolstant nuo oro uosto (Martin, 2006). Tokio pobūdžio tyrimai ypač populiarūs JAV ir Vakarų Europoje (Prancūzijoje, Vokietijoje, Didžiojoje Britanijoje, Italijoje ir Rusijoje). Kitose valstybėse jie irgi vykdomi, tik mažesniu mastu. Pabrežtina, kad kraštovaizdžio akustinès aplinkos tyrimuose didžiausias dèmesys skiriamas garso kokybei (tembrui) ìvertinti, visais būdais stengiamasi ji mažinti. Šie aspektai atsispindi ir Europos Sąungos direktyvoje „Aplinkos garsu valdymas ir ivertinimas“, kurios pagrindinis tikslas yra garsu kontroles ir ívertinimo metodų pagerinimas siekiant sumažinti ju poveiki (Papdimitriou ir kt., 2009). Pusiau urbanizuotos ir kaimiškosios vietovès yra įdomios atliekant mokslinius tyrimus. Tokio pobūdžio teritorijose galimas kartografavimas išskiriant tyliuosius kaimiškųjų vietovių arealus. Kaimiškosios garsinès aplinkos tyrimai gali būti orientuojami i kraštovaizdžio ekologiją, analizuojami gyvosios gamtos garsai. Be to, labai svarbi akustinèje kraštovaizdžio struktūroje yra harmoninga garsinè aplinka, kuri suteikia tam tikrų pojūčių būnant joje ir gali būti tyrinejama psichologiniu aspektu turizmo geografijoje. Hidrofoniniai, biofoniniai garsai yra įrašomi terapiniais tikslais (paukščių, bangu mūšos, upès šniokštimo garsai). Garsinė aplinka gali būti tyrinejjama saugomose teritorijose kaip išskirtinis garsinis šių teritorijų fonas. Pavyzdžiui, Jungtinių Amerikos Valstijų nacionaliniuose parkuose akustinè aplinka yra saugoma (Miller, 2008). Visi ten ịrašyti garsai yra labai svarbūs, nes atskleidžia tam tikros vietos garsinès aplinkos išskirtinumą ir unikalumą.

Garso intensyvumui kraštovaizdyje matuoti gali būti naudojamos automatinès skaitmeninès i̇rašymo sistemos. Garso fiksavimo prietaisais identifikuoti garsai yra įrašomi atsižvelgiant i garsų trukmę ir intensyvumą, o tai leidžia signalo procesoriams atkurti jų dažni per laiko vienetą. Garso stiprumas (intensyvumas) dažniausiai išreiškiamas decibelais $(\mathrm{dB})$. Sklindančius garsus galima užregistruoti spektrografu. Gaunama spektrograma, kuri turi tris garso dimensijas: laiką, dažnị ir amplitudę. Joje užfiksuotus garsus galima detaliai analizuoti, toks metodas ypač populiarus akustinio kraštovaizdžio ekologijos tyrimuose. Čia spektrogramos naudojamos analizuojant gamtos (geofoninius, biofoninius) ir antropofoninius garsus, bet dažniausiai tokio pobūdžio tyrimai taikomi tiriant gyvūnų garsus, ypač paukščių. Kartografuodami akustinès aplinkos savybes laiko ir erdvès kontekste gauname rezultatus, kuriuos galime pritaikyti ekosistemų raidos tyrimuose, kitų geografijos sričiu poreikiams, planuodami teritorijas, analizuodami kitokio pobūdžio garso specifiką.

Svarbus terminas naudojant ir tiriant garsinę aplinką yra sonotopas, turintis dar kelias darybos 
prasme panašias, bet pagal apimamą turinị ir apibrèžtį kitokias variacijas - soundtopas ir sonotonas. Sonotopas yra teritorinis vienetas, aprepiantis panašų geofoninių, biofoninių ar antropotechnofoninių garsų derini (Farina, 2014), kuris formuojasi, sklinda ir bègant laikui kinta pagal vienodus principus. Sonotopai išskiriami remiantis tam tikro kraštovaizdžio "garsinio lopinèlio" išsidèstymu bègant laikui ir erdvéje, jis taip pat atspindi garso kokybę, jo atsiradimo laiką, išsidèstymo ir kaitos erdveje ypatumus. Tačiau sonotopų išskyrimas lokalinèje kraštotvarkoje vis dar kelia neaiškumų ir jų skyrimo bei vertinimo problema iki šiol neturi pakankamo metodologinio pagrindo (Kavaliauskas, 2011). Sonotopai kraštovaizdyje gali būti identifikuojami tiriant kraštovaizdžio arealo morfologinę struktūrą, kurios sudètis tiesiogiai turi įtakos vietos akustinès sandaros ypatumams. Mokslinejje literatūroje terminas „soundtopas“ (angl. soundtope) neretai traktuojamas kaip dalis sonotopo, nors darybos prasme jis tapatus sonotopui. „Soundtopas“ generuojamas ir fiksuojamas tik gyvūnų bendruomenèse ir gali būti tapatinamas su vieta, kur skleidžiami ìspejjamieji signalai. „Sonotonai“ (angl. sonotone) yra kažkas panašaus kaip ekotonai ir traktuojami kaip pereinamosios juostos tarp skirtingu sonotopų.

Iš mokslininkų darbų, tiriančių akustiką ir akustikos psichologiją, yra sužinomos fizinès garso savybès, garso kaip reiškinio psichofiziologinio suvokimo procesas - sklidimo kelias link žmogaus smegenų. Iš visuomenès yra sužinoma, kaip garsai veikia žmonių elgesị ir kaip žmonès reaguoja $\mathfrak{i}$ ívairius garsus. Muzikologine prasme aplinkos garsai yra kaip muzikinè kompozicija. Iš to gimsta akustinis dizainas, kuris turi estetinę sąsają su kraštovaizdžiu, kai analizuojamas garsas ir jo kaitos procesai, kraštovaizdžio garsinè aplinka su žmogumi ir aplinka (Schafer, 1993). Garsinès aplinkos tyrimai turi ne tik pažintinę-mokslinę, bet ir praktinę prasmę. Tokio pobūdžio tyrimų plètra padètu geriau ir tiksliau ịvertinti momentinę vietos kraštovaizdžio garsinę struktūrą, suvokti jos dinamiką ìvairiuose laiko intervaluose, padètų atlikti kokybinị palyginamąjł vertinimą, identifikuoti vertès ir išskirtinumo savybiu turinčius sonotopus. Sonotopai galètų tapti kaip saugotina, konkrečią teritoriją reprezentuojanti ir iš kitų teritorijų išskirianti bei gyvenimo kokybę, rekreacini atraktyvumą didinanti vertybè. Galiausiai platesni tokio pobūdžio tyrimai sudarytų galimybes išskirti nagrinejamos teritorijos (regioniniu ar valstybiniu lygmeniu) garso struktūros ir dinamikos požiūriu vienalyčių kraštovaizdžio elementų (teritorinių vienetų) sonotopus.

\section{IŠVADOS}

1. Nors kraštovaizdžio akustinès struktūros ištyrimo lygis vis dar yra žemas, tobulejančios technologijos ir didejantis jų prieinamumas sudaro vis palankesnes sąlygas tokio pobūdžio kraštovaizdžio tyrimų raiškai.

2. Akustinio kraštovaizdžio terminas gali būti diskusinio pobūdžio dèl panašių jam terminų vartojimo, be to, dèl tarpdisciplininès tyrimų srities šios sąvokos nèra tvirtai nusistovejusios.

3. Bendrojoje akustinio kraštovaizdžio struktūrinèje schemoje identifikavus ịvairaus pobūdžio gamtinius ir antropogeninius garso šaltinius (fonijas) būtina konstatuoti, kad esminiu akustini kraštovaizdi formuojančiu veiksniu išlieka vietos geografinè padètis su visais kitais jai būdingais akustines savybes veikiančiais atributais (klimato sąlygomis, vietovès kraštovaizdžio ypatybėmis, ju kaita per parą ir metus).

4. Akustinio kraštovaizdžio tyrimai kraštovaizdžio geografijoje ir kraštotvarkoje daugiausia sutelkti urbanizuotose teritorijose, kur aktualiausia garso taršos problema. Populiarūs yra ekologinio pobūdžio akustinio kraštovaizdžio tyrimai, atskleidžiantys pagrindines akustinès aplinkos savybes, iš kurių svarbiausios yra garso kaita bègant laikui ir erdveje.

5. Vykdant akustinio kraštovaizdžio tyrimus būtina integruoti įvairias mokslinio pažinimo sritis tam, kad pavyktų efektyviau spręsti tipiškos ir išskirtinès akustinès aplinkos pažinimo bei apsaugos problemas.

6. Plètojami akustinio kraštovaizdžio tyrimai padètu geriau ir tiksliau îvertinti momentinę vietos kraštovaizdžio garsinę struktūrą, suvokti jos dinamiką ịvairiuose laiko intervaluose. Be to, visa tai iggalintų atlikti kokybinị palyginamajj vertinimą identifikuojant vertès ir išskirtinumo savybių turinčius sonotopus.

Gauta 20180417

Priimta 20180618 


\section{LITERATŪRA}

1. Andrews C. G. 2013. Soundscape Ecology: A Real Conservation Tool or Exercise in Nostalgia? http:// goodnature.nathab.com/soundscape-ecology-areal-conservation-tool-or-exercise-in-nostalgia/

2. Brooks B. M. 2014. Exploring our sonic environment through soundscape research \& theory. Acoustics Today. 10(1): 30-40.

3. Dubois D. et al. 2016. Acoustic environments and soundscapes. In: J. Kang; B. Schulte-Fortkamp (eds.). Soundscape and the Built Environment. CRC Press.

4. Erbe C. et al. 2016. The underwater soundscape around Australia. Conference: Acoustics 2016. Brisbane. 1-10.

5. Farina A. 2014. Soundscape Ecology: Principles, Patterns, Methods and Applications. Netherlands: Springer.

6. Farina A., Pieretti N. 2012. The soundscape ecology: A new frontier of landscape research and its application to islands and coastal systems. Journal of Marine and Island Cultures. 1(1): 21-26.

7. Féron A. 2017. Paysage sonore. https://www.universalis.fr/encyclopedie/paysage-sonore/

8. Gedutis A. 2016. Klaipèdos garsovaizdis (I): (ne) girdètas miestas. Sociologija. Mintis ir veiksmas. 38(1): 117-130.

9. Geisler É. 2013. Du "soundscape" au paysage sonore. http://www.metropolitiques.eu/Du-soundscapeau-paysage-sonore.html
10. Holmes D. 2016. Immersing yourself into the acoustic environment - "Soundscapes". http://www2.supsi. $\mathrm{ch} / \mathrm{cms} /$ tsw/wpcontent/uploads/sites/22/2016/07/ FW_Sounds_Royalgeogr.pdf

11. Kavaliauskas P. 2011. Kraštovaizdžio samprata ir planavimas: mokomoji knyga. Vilnius: Vilniaus universitetas. http://www.gkk.gf.vu.lt/old/Data/Metodines\%20priemones/Krast_SMPR_PLNV.pdf

12. Miller P. N. 2008. US National Parks and management of park soundscapes: a review. Applied Acoistics. 69(2): 77-92.

13. Papadimitriou K. et al. 2009. Mapping the variations of a rural soundscape. The case study of Antinioti, Greece. Conference: WFAE 2009 "Sound Megalopolis, Cultural Identity and Sound in Danger of Extinction". Mexico.

14. Pijanowski C. B. et al. 2011. Soundscape ecology: the science of sound in the landscape. BioScience. 61(3): 203-2016.

15. Radicchi A. 2013. Emotional geography \& soundscape studies: beyond the cognitive approach in (sound) mapping urban spaces. Conference: the EAEA11 Envisioning Architecture: Design, Evaluation, Communication.

16. Schafer M. R. 1993. The Soundscape: Our Sonic Environment and the Tuning of the World. Rochester: Destiny Books.

17. Winkler J. Et al. 1999. Klanglandschaft wörtlich. Akustische Umwelt in transdisziplinärer Perspektive. Herausgegeben vom Forum Klanglandschaft. Basel. 3. 


\section{Ričardas Skorupskas, Saulius Jaruševičius}

\section{SOUNDSCAPE CONCEPTION AND ITS RESEARCH PECULIARITIES}

\section{Su m mary}

This scientific field has been developing since the second half of the 20th century. Although this research field has been relevant for more than 50 years; however, it has plenty of various approaches, because it is an interdisciplinary research field. The landscape structure and sound environment are strongly interconnected. The interfaces are visible through the landscape morphology, vegetation structure, human infrastructure and settlements and the distribution of animals in it; all these elements create the various environmental sounds and the particular spreading conditions. In the landscape there are plenty of sound sources, but the major are three. Geophonies are the result of sonic energy produced by non-biological natural agents such as winds, volcanoes, sea waves. Biophonies are the result of animal vocalizations (songs, contact and alarm calls, voices). Anthrophonies are the result of all the sounds produced by technical devices (engines, blades, wheel revolutions, industries, etc.). But such classification is not precise; therefore, to be more accurate it should be split further. As a result, geophony consists of hydrophony (flowing sounds of the water) and lithophony (sounds created in contact with the earth's surface). This classification also includes sounds produced by the plants. In anthrophony, we could distinguish two types of sounds: anthrophony as sounds of people themselves and technophony as sounds of technical devices - it can be called anthropotechnophony. Therefore, meteorological phenomena have influence on all sounds in the landscape. Geographically, the main factors influencing the dynamics of sounds are the geographical location of the area, the climate conditions, and the daily cycle. These all sound sources can produce low fidelity (lo-fi) sounds that are clear and can be heard from one main sound source and high fidelity (hi-fi) sounds that are very unclear and unpleasant. The various spread of sound is significant in different latitudes and in the areas of altitudinal zonation. It is determined by many geographical factors, among which the most important are climatic conditions, the characteristics of the surface area, vegetation, the diversity of flora, population density, the degree of anthropogenic load, etc. In mountain areas, the spread of sound is characterized by different specific features. First of all it depends on the geographic latitude and on climatic conditions, the height of the snowline and the nature of vegetation. In addition, geomorphological features of the mountains are also important - the steepness and location of the slope. Currently, landscape sound is increasingly developing in various aspects, but research is often focused on noise pollution in urban and suburban areas. The soundscape ecology has become more popular in recent decades. This includes the assignment of the soundscape to the geographic context, the identification of anthropogenic and biological processes, and spectral and temporal patterns in the soundscape, how organisms perceive spatial configuration in landscapes, etc. An underwater acoustic environment should also be explored. Studies of the landscape's sound environment can also be carried out in rural areas, as well as studies relevant to landscape architecture. In psychological aspect it is important in tourism geography studies. The mapping of the space of acoustic environment - time change and its properties can be applied to geographic analysis, ecosystem evolution, landscape management, urban and rural planning, and analysis of sound specifics.

Keywords: soundscape, soundscape structure, sonotopes, sonic environment, apllied landscape research 